\title{
КАК СОЗДАТЬ НОВЫЙ АНТИСЕПТИК? ОТ ИДЕИ ДО РЕАЛИЗАЦИИ
}

\author{
А.Н. Верещагин \\ Институт органической химии им. Н.Д. Зелинского РАН, \\ 119334, Россия, Москва, Ленинский проспект, 47.
}

DOI: 10.19163/MedChemRussia2021-2021-30

E-mail: vereshchsgin@ioc.ac.ru

В настоящее время на Российском рынке медицинских изделий значительная часть антисептических средств сделано на основе четвертичных аммониевых соединений (ЧАС). Наиболее известные и эффективные антисептики на основе моно-ЧАС - бензалконий хлорид, цетилпиридиний хлорид, мирамистин, на основе бис-ЧАС - хлоргексидин, алексидин, октенисепт, местамидин. Известно, что различные штаммы бактерий, в том числе патогенных со временем вырабатывают резистентность к противомикробных лекарственным средствам., ${ }^{1,2}$

В настоящей работе предложен оригинальный подход к синтезу нескольких новых типов ЧАС на основе солей пиридина. Путем варьирования спейсера между двумя пиридиниевыми ядрами получены бис-ЧАС, обладающие антибактериальной и противогрибковой активностью против широкого спектра высокорезистентных патогенных бактерий (как грамположительных, так и грамотрицательных) и грибов, превосходящей активность известных антисептиков. Особо следует отметить, что новые ЧАС успешно испытаны против высокорезистентных клинических штаммов, выделенных из клинических образцов при расследовании случаев инфекций в 2016-2018 гг.

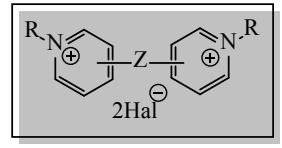

$\mathrm{R}=\mathrm{C}_{\mathrm{n}} \mathrm{H}_{2 \mathrm{n}+1}, \mathrm{n}=7-16$

$\mathrm{Hal}=\mathrm{Cl}, \mathrm{Br}, \mathrm{I}$

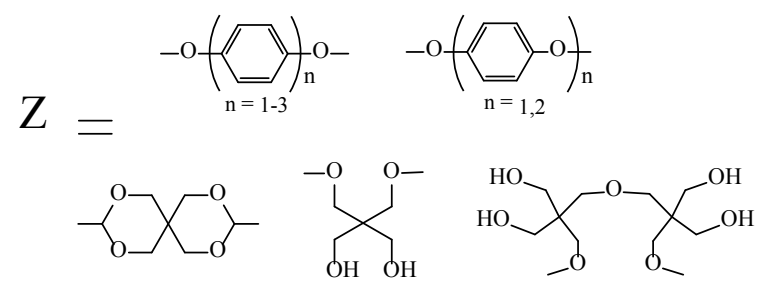

References

[1] L. Thomas, J.-Y. Maillard, R.J. Lambert, A.D. Russell, J. Hosp. Infect. 2000, 46, 297.

[2] M.J. Shepherd, G. Moore, M.E. Wand, J.M. Sutton, L.J. Bock, J. Hosp. Infect. 2018, 100, e23. 